\title{
Analisis Perbedaan Tingkat Kelulusan Computer Based Test Uji Kompetensi Mahasiswa Program Profesi Dokter Berdasarkan Tingkat Kehadiran pada Kegiatan Pembekalan di Fakultas Kedokteran Universitas Riau
}

\author{
Firdaus $^{1, *}$, Chairunnisa ${ }^{2}$, Rita Endriani ${ }^{3}$
}

\begin{abstract}
Tutoring of UKMPPD is a preparation effort in the form of tutoring activities to get more optimal understanding and results for UKMPPD. The purpose of the research was to analyze the differences in the pass rates of UKMPPD-CBT based on attendance levels in the UKMPPD tutoring activities at the Medical Faculty of Riau University. The design of this research was a comparative analytic with a retrospective approach. The result was using Mann Whitney U Test obtained sig (2-tailed) $0.010(<0.05)$, it showed there was a significant difference between the results of passing UKMPPD-CBT for the group that took the tutoring and the group that did not take the tutoring. The research also used the Kruskall Wallis analysis test and obtained sig (2-tailed) $0.000(<0.05)$, it showed there was a significant difference between the UKMPPD-CBT passing results and the attendance level of first taker students in UKMPPD tutoring activities.
\end{abstract}

Keywords: First taker students, UKMPPD tutoring, UKMPPD-CBT

Uji Kompetensi Mahasiswa Program Profesi Dokter (UKMPPD) adalah suatu exit exam atau uji pencapaian kompetensi dokter terstandar secara nasional yang harus dilewati mahasiswa pada akhir fase pendidikan profesi dokter. ${ }^{1}$ Pada beberapa tahun pelaksanaan ujian kompetensi, muncul permasalahan baru yaitu semakin bertambahnya jumlah mahasiswa peserta ujian kompetensi yang tidak lulus. ${ }^{2}$ Oleh sebab itu pemerintah mengantisipasi permasalah ini dengan memberikan tanggung jawab kepada setiap institusi penyelenggara pendidikan profesi dokter untuk memberikan program bimbingan berupa pembekalan kepada setiap mahasiswa calon peserta UKMPPD. ${ }^{3}$ Kegiatan pembekalan dilaksanakan agar mahasiswa peserta UKMPPD bisa mendapatkan hasil yang lebih optimal dalam menghadapi UKMPPD. ${ }^{4}$

\footnotetext{
* Corresponding author: dr.firdaus@lecturer.unri.ac.id

1 KJFD Ilmu Pendidikan Kedokteran, Fakultas Kedokteran Universitas Riau, Pekanbaru, Riau.

2 Program Studi Kedokteran Fakultas Kedokteran Universitas Riau, Pekanbaru, Riau.

3 KJFD Mikrobiologi Fakultas Kedokteran Universitas Riau, Pekanbaru, Riau.
}

Institusi-institusi penyelenggara pendidikan kedokteran terus melakukan perbaikan kegiatan pembekalan untuk meningkatkan performa mahasiswa peserta didiknya, sehingga hal ini mempengaruhi hasil UKMPPD dan meningkatkan kualitas lulusan dari institusi tersebut. ${ }^{5}$ Hasil penelitiannya yang dilakukan di Fakultas Kedokteran Universitas Abulyatama menyimpulkan bahwa bimbingan belajar memiliki hubungan yang signifikan dengan kelulusan UKMPPD-CBT. ${ }^{4}$

Fakultas Kedokteran Universitas Riau melakukan pembekalan UKMPPD sebagai upaya peningkatan persentase kelulusan UKMPPD di Fakultas Kedokteran Universitas Riau. Pembekalan UKMPPD di Fakultas Kedokteran Universitas Riau terdiri dari pre-test, diskusi pakar dan post-test sebagai bekal bagi mahasiswa dalam menghadapi UKMPPD. Metode pembekalan UKMPPD semacam ini adalah merupakan metode dengan pendekatan Assessment for learning, tujuannya yaitu untuk mengoptimalkan kemampuan mahasiswa kedokteran dengan simulasi test, memberikan arahan dalam belajar melalui feedback yang diberikan, memotivasi, membantu 
mahasiswa memantau progresnya dalam belajar sehingga berhasil memperoleh hasil optimal. ${ }^{6}$

Berdasarkan data sekunder yang diperoleh dari Unit Asesmen Fakultas Kedokteran Universitas Riau adanya permasalahan dalam pelaksanaan pada kegiatan pembekalan UKMPPD di Fakultas Kedokteran Universitas Riau, yaitu banyak mahasiswa first taker yang tidak menghadiri kegiatan pembekalan UKMPPD. Tujuan dari penelitian ini yaitu untuk mengetahui perbedaan hasil UKMPPD-CBT yang diperoleh mahasiswa first taker yang mengikuti kegiatan pembekalan dan mahasiswa first taker yang tidak mengikuti kegiatan pembekalan yang diselenggarakan oleh Fakultas Kedokteran Universitas Riau pada tahun 2019.

\section{METODE}

Penelitian ini merupakan penelitian analitik komparatif dengan pendekatan cross sectional. Pada penelitian ini dilakukan analisis perbedaan tingkat kelulusan UKMPPD-CBT mahasiswa first taker berdasarkan tingkat kehadiran pada kegiatan pembekalan menggunakan uji Mann Whitney U Test dan Kruskall Wallis. Data penelitian ini diperoleh dari data sekunder yaitu database yang didapat dari Unit Asesmen Fakultas Kedokteran Universitas Riau. Populasi dari penelitian ini adalah mahasiswa first taker UKMPPD di Fakultas Kedokteran Universitas Riau periode Februari, Mei, Agustus dan November tahun 2019. Seluruh populasi pada penelitian ini menjadi sampel penelitian (total sampling). Penelitian telah mendapatkan persetujuan etik dari Unit Etika Penelitian Kedokteran / Kesehatan Fakultas Kedokteran Universitas Riau, Nomor: 093/ UN.19.5.1.1.8/UEPKK/2020.

\section{HASIL}

Penelitian ini diikuti oleh 136 mahasiswa yang merupakan first taker dalam pelaksanaan UKMPPD periode Februari, Mei, Agustus dan November tahun 2019.

Tabel 1. Gambaran hasil UKMPPD-CBT yang diperoleh pada mahasiswa first taker Fakultas Kedokteran Universitas Riau tahun 2019

\begin{tabular}{lccccccc}
\hline & \multicolumn{2}{c}{ Lulus } & \multicolumn{2}{c}{ Tidak Lulus } & \multicolumn{2}{c}{ Total } \\
\cline { 2 - 7 } Hasil UKMPPD-CBT & $\mathbf{n}$ & \% & n & \% & n & \% \\
\cline { 2 - 7 } & \multirow{2}{*}{115} & & \multirow{2}{*}{84,56} & 21 & 15,44 & 136 & 100 \\
\hline
\end{tabular}

Berdasarkan hasil penelitian pada tabel 1, dapat dilihat mahasiswa first taker yang lulus UKMPPDCBT yaitu sebanyak 115 orang atau sebesar $84,56 \%$ sedangkan mahasiswa first taker yang tidak lulus sebanyak 21 dengan persentase sebesar 15,44\%.

Tabel 2. Gambaran keikutsertaan mahasiswa first taker Fakultas Kedokteran Universitas Riau pada kegiatan pembekalan pada tahun 2019 .

\begin{tabular}{|c|c|c|c|c|c|c|c|c|c|c|}
\hline \multirow{4}{*}{$\begin{array}{c}\text { Keikutsertaan } \\
\text { mahasiswa first taker } \\
\text { UKMPPD tahun } 2019\end{array}$} & \multicolumn{8}{|c|}{ Mengikuti Pembekalan } & \multirow{2}{*}{\multicolumn{2}{|c|}{ Total }} \\
\hline & \multicolumn{2}{|c|}{$\begin{array}{l}\text { Tidak Mengikuti } \\
\text { Pembekalan }\end{array}$} & \multicolumn{2}{|c|}{$\begin{array}{c}\text { Kehadiran } \\
<100 \%\end{array}$} & \multicolumn{2}{|c|}{$\begin{array}{c}\text { Kehadiran } \\
100 \%\end{array}$} & \multicolumn{2}{|c|}{ Jumlah } & & \\
\hline & $\mathbf{n}$ & $\%$ & $\mathbf{n}$ & $\%$ & $\mathbf{n}$ & $\%$ & $\mathbf{n}$ & $\%$ & $\mathbf{n}$ & $\%$ \\
\hline & 15 & 11 & 60 & 44,1 & 61 & 44,9 & 121 & 89 & 136 & 100 \\
\hline
\end{tabular}


Pada tabel 2 dapat dilihat bahwa jumlah mahasiswa first taker yang mengikuti pembekalan UKMPPD adalah sebanyak 121 orang (89\%) yang terdiri dari kelompok mahasiswa dengan kehadiran $100 \%$ yaitu 61 orang $(44,9 \%)$ dan kelompok mahasiswa dengan kehadiran $<100 \%$ yaitu 60 orang $(44,1 \%)$ sedangkan jumlah mahasiswa first taker yang tidak mengikuti pembekalan yaitu sebanyak 15 orang $(11 \%)$.

Tabel 3. Perbedaan hasil UKMPPD-CBT yang diperoleh mahasiswa first taker berdasarkan keikutsertaan pada kegiatan pembekalan yang diselenggarakan oleh Fakultas Kedokteran Universitas Riau pada tahun 2019

\begin{tabular}{lccc}
\hline \multirow{2}{*}{ Kelompok } & \multicolumn{2}{c}{ Hasil UKMPPD CBT } & \multirow{2}{*}{ Sig. (2-tailed) } \\
\cline { 2 - 3 } & $\mathbf{n}$ & Mean & \\
\hline Mengikuti pembekalan & 121 & 71,55 & \multirow{2}{*}{0,010} \\
Tidak Mengikuti pembekalan & 15 & 43,93 & \\
Total & 136 & & \\
\hline
\end{tabular}

Berdasarkan tabel di atas menunjukkan ratarata hasil UKMPPD-CBT tiap kelompok yaitu pada kelompok yang mengikuti pembekalan adalah sebesar 71,55 lebih tinggi dari pada ratarata kelompok yang tidak mengikuti pembekalan yaitu 43,93. Hasil uji Mann Whitney terhadap hasil UKMPPD-CBT kelompok yang mengikuti pembekalan dan yang tidak mengikuti pembekalan diperoleh nilai sig (2-tailed) sebesar $0.010(<0.05)$. Hal ini berarti terdapat perbedaan bermakna hasil UKMPPD-CBT antara kedua kelompok, kelompok mahasiswa first taker yang mengikuti kegiatan pembekalan memiliki nilai rata-rata UKMPPDCBT lebih tinggi secara bermakna dibandingkan dengan mahasiswa first taker yang tidak mengikuti pembekalan.

Tabel 4. Perbedaan hasil UKMPPD-CBT yang diperoleh mahasiswa first taker berdasarkan tingkat kehadiran dalam mengikuti kegiatan pembekalan yang diselenggarakan oleh Fakultas Kedokteran Universitas Riau pada tahun 2019

\begin{tabular}{|c|c|c|c|}
\hline \multirow[b]{2}{*}{ Keikutsertaan dalam kegaiatan Pembekalan } & \multirow{2}{*}{$\mathbf{N}$} & ККМPPD CBT & \multirow[b]{2}{*}{ Asymp. Sig. } \\
\hline & & Mean & \\
\hline Kehadiran $100 \%$ & 61 & 83,29 & \multirow{4}{*}{0,000} \\
\hline Kehadiran $<100 \%$ & 60 & 59,81 & \\
\hline Tidak Hadir & 15 & 43,13 & \\
\hline Total & 136 & & \\
\hline
\end{tabular}

Tabel di atas menunjukkan hasil UKMPPDCBT tiap kelompok yaitu pada kelompok dengan kehadiran $100 \%$ adalah sebesar 82,39 dan merupakan kelompok dengan rata-rata tertinggi, kemudian kelompok dengan kehadiran $<100 \%$ adalah sebesar 59,81 dan kelompok yang tidak hadir pembekalan yaitu 43,13. Hasil uji Kruskall Wallis diperoleh nilai sig (2-tailed) sebesar $0.000(<0,05)$ yang berarti terdapat perbedaan bermakna hasil rata-rata UKMPPD-CBT antara ketiga kelompok. Hasil UKMPPD-CBT mahasiswa first taker dengan tingkat kehadiran $100 \%$ memiliki nilai lebih tinggi secara bermakna jika dibandingkan dengan mahasiswa first taker dengan kehadiran kurang dari 100\% dan yang tidak menghadiri kegiatan pembekalan.

\section{PEMBAHASAN}

Berdasarkan hasil kelulusan UKMPPDCBT mahasiswa first taker Fakultas Kedokteran Universitas Riau pada tahun 2019 yaitu jumlah mahasiswa yang lulus sebanyak 115 orang $(84,56 \%)$ dan jumlah mahasiswa yang tidak lulus sebanyak 21 orang $(15,44 \%)$. Hasil ini dapat dikatakan baik karena jumlah persentase kelulusan mahasiswa first taker Fakultas Kedokteran Universitas Riau lebih 
tinggi dibandingkan dengan jumlah persentase kelulusan UKMPPD-CBT nasional pada tahun 2019 yaitu sebesar 57,1\%. Angka persentase mahasiswa first taker Fakultas Kedokteran Universitas Riau yang tidak lulus pada UKMPPD-CBT tahun 2019 sebesar 15,44\% adalah lebih kecil jika dibandingkan dengan angka persentase nasional mahasiswa first taker yang tidak lulus, yaitu sebesar $41,11 \%$.

Berdasarkan keikutsertaan mahasiswa first taker pada kegiatan pembekalan UKMPPD-CBT di Fakultas Kedokteran Universitas Riau pada tahun 2019, jumlah mahasiswa first taker yang mengikuti kegiatan pembekalan yaitu sebanyak 121 orang $(89 \%)$, dan mahasiswa first taker yang tidak mengikuti pembekalan yaitu sebanyak 15 orang (11\%). Informasi yang diperoleh dari mahasiswa first taker pada tahun 2019 yang tidak mengikuti pembekalan UKMPPD disebabkan karena beberapa faktor, yaitu terdapat mahasiswa yang masih menjalani stase koas, mengikuti bimbingan belajar di luar kampus dan ada juga mahasiswa yang memilih untuk belajar sendiri.

Analisa hasil UKMPPD-CBT mahasiswa first taker berdasarkan keikutsertaan pada kegiatan pembekalan menggunakan uji Mann Whitney menunjukan perbedaan signifikan, mahasiswa yang mengikuti pembekalan memiliki hasil UKMPPDCBT yang lebih tinggi secara bermakna. Hasil uji Kruskall Wallis menunjukan hasil UKMPPD-CBT mahasiswa first taker dengan tingkat kehadiran $100 \%$ pada kegiatan pembekalan lebih tinggi secara bermakna jika dibandingkan dengan mahasiswa dengan tingkat kehadiran kurang dari $100 \%$ dan mahasiswa yang tidak mengikuti kegiatan pembekalan. Hal ini menunjukan bahwa tingkat kehadiran mahasiswa dalam kegiatan pembekalan mempengaruhi hasil UKMPPD mereka, dan metode pada kegiatan pembekalan berpengaruh terhadap persiapan serta hasil yang diperoleh mahasiswa pada UKMPPD-CBT.

Metode belajar yang diterapkan pada kegiatan pembekalan berupa tes formatif berbentuk pretest, efektif memfasilitasi mahasiswa melakukan persiapan menghadapi ujian UKMPPD. Metode ini merupakan salah bentuk penerapan assessment for learning yang memandu proses belajar mahasiswa first taker melalui latihan soal sebelum mengikuti ujian utama yaitu UKMPPD-CBT. Assessment for learning dapat membantu mahasiswa lebih efektif mempersiapkan diri menghadapi suatu ujian utama. ${ }^{7}$ Pada umumnya mahasiswa dalam mempersiapkan dirinya untuk suatu ujian utama harus menghabiskan waktu berjam - jam hanya untuk menemukan bahwa suatu topik atau materi penting untuk dipelajari. ${ }^{8}$ Memanfaatkan assessment sebagai pendekatan pembelajaran selain berperan dalam proses pengkodean memori juga bermanfaat memfokuskan mahasiswa pada konten prioritas dengan memberikan umpan balik objektif tentang akuisisi konten. ${ }^{8,9}$

Umpan balik dari suatu Assessment for learning merupakan elemen penting dalam regulasi belajar mahasiswa secara mandiri. ${ }^{10,11}$ Metode pembekalan yang memanfaatkan umpan balik dari serangkain hasil pretest, memberikan arah belajar bagi peserta pembekalan, memberikan informasi topik dan materi yang perlu mendapat perhatian oleh para peserta pembekalan. Umpan balik dari hasil pretest yang diberikan kepada mahasiswa memiliki efek positif pada pembelajaran dan kinerja mahasiswa. ${ }^{12,10}$

Penggunaan Assessment sebagai konsep pendekatan pembelajaran ditopang oleh berbagai teori dan temuan empiris dari berbagai disiplin ilmu. ${ }^{13}$ Penggunaan Assessment sebagai konsep pendekatan pembelajaran yang efektif, didasarkan bahwa pendekatan ini membangkitkan aktivitas mental yang baik pada mahasiswa melalui pengalam tes formatif yang dihadapinya. ${ }^{14}$ Mahasiswa yang terpapar oleh suatu tes formatif biasanya mengalami peningkatan yang signifikan dalam kemampuan mereka untuk mengingat kembali materi yang diajarkan dibandingkan dengan mahasiswa yang hanya mempelajari kembali atau membaca ulang materi pembelajarannya. Hal ini dikarenakan memori manusia tidak bersifat statis, melatih memori dengan tes memiliki efek yang kuat pada penguatan memori, pengingatan aktif dari pengetahuan sebelumnya membuat memori spesifik menjadi lebih kuat. ${ }^{15}$

Pada penelitian ini didapatkan bawah mahasiswa dengan kehadiran $100 \%$ pada kegiatan pembekalan memiliki hasil UKMPPD-CBT lebih tinggi secara bermakna. Hal ini dikarenakan mahasiswa dengan kehadiran 100\% akan lebih sering berlatih, sehingga memiliki pemahaman serta regulasi belajar yang lebih baik. Serangkain pretest bisa menjadi katalis untuk memudahkan bagi mahasiswa dalam 
mengingat kembali pengetahuan yang telah mereka miliki dan mengingat pengetahuan tersebut lebih lama. Hal ini dianggap sebagai mekanisme utama dari efek Assessment yang digunakan sebagai pembelajaran. ${ }^{16}$ Pemanfaatan assessment sebagai pendekatan pembelajaran adalah mengacu pada sifat asosiatif memori manusia, yang menghubungkan pengetahuan yang didapat sebelumnya dengan penerapan pengetahuan di masa datang yang dikemas pada soal yang diujikan. ${ }^{16,17}$ Dengan demikian kehadiran mahasiswa dalam kegiatan pembekalan UKMPPD merupakan salah satu faktor penting terhadap kelulusan UKMPPD-CBT.

\section{SIMPULAN}

Mahasiswa first taker yang mengikuti kegiatan pembekalan memiliki hasil UKMPPD-CBT lebih tinggi secara bermakna jika dibandingkan dengan mahasiswa yang tidak mengikuti kegiatan pembekalan. Tingkat kehadiran mahasiswa pada kegiatan pembekalan mempengaruhi hasil UKMPPD mahasiswa secara bermakna. Mahasiswa dengan tingkat kehadiran $100 \%$ pada kegiatan pembekalan memiliki hasil UKMPPD-CBT lebih tinggi secara bermakna jika dibandingkan dengan mahasiswa yang tingkat kehadirannya kurang dari $100 \%$ dan yang tidak mengikuti kegiatan pembekalan.

\section{DAFTAR PUSTAKA}

1. Suswati I, \& Rahayu D. Validitas prediktif uji kompetensi mahasiswa program profesi dokter (ukmppd) pada tahap profesi. Saintika Medika. 2017;13(2):118. https://doi.org/10.22219/ sm.v13i2.5553

2. DIKTI. Uji Kompetensi Dokter Indonesia sebagai exit exam. 2013;88:0-24.

3. Menteri Pengajaran dan Kebudayaan. Peraturan Menteri Pengajaran dan Kebudayaan: Permendikbud/30/2014. Indonesia: Kemendikbud RI. 2014.

4. Lidiawati M. Hubungan bimbingan belajar UKMPPD dengan kelulusan UKMPPD Computer Based Test Fakultas Kedokteran Universitas Abulyatama periode Mei 2017. Jurnal Dedikasi Pendidikan. 2018;2(1):63-7.
5. Siregar FM, Nurcahyo GW, Defit S. Prediksi hasil Ujian Kompetensi Mahasiswa Program Profesi Dokter (UKMPPD) dengan pendekatan ANFIS. Jurnal RESTI. 2018;2(2):554-9. https:// doi.org/10.29207/resti.v2i2.388

6. Epstein RM. Assessment in medical education. N Engl J Med. 2007;356(20):387-96.

7. Guskey, T. R. Twenty questions? Twenty tools for better teaching. Principal Leadership 2000; 1(3):5-7.

8. Roediger HL, Agarwal PK, McDaniel MA, McDermott KB. Test-enhanced learning in the classroom: long-term improvements from quizzing'. J Exp Psychol Appl 2011; 17(4):382395

9. Schwartz DL, Martin T. Inventing to prepare for future learning: the hidden efficiency of encouraging original student production in statistics instruction. Cogn Instr 2004 ; 22(2):129-184.

10.Nicol.DJ, Macfarlane.,DD. Macfarlane Formative assessment and self-regulated learning: A modeland seven principles of good feedback practice. Studies in Higher Education. 2006 ; 31(2):199-218.

11.Clark.I. Formative Assessment : Assessment is for self- regulated learning. Educational Psychology Review. 2012 ;24 (2):205-249.

12.Hattie J, Timperley H. The power of feedback. Review of Educational Research. 2007 ; 77(1):81-112.

13.Kulasegaram, K and Rangachari.P, Beyond : formative: assessments to enrich student learning. Advances Physiol Educ 2018 42(1), pp 5-14

14.Kulasegaram K, Chaudhary Z, Woods N, Dore K, Neville A, Norman G. Contexts, concepts and cognition: principles for the transfer of basic science knowledge. Med Educ 2017; 5(1):184195.

15.Kornell $\mathrm{N}$ and Vaughn KE. How retrieval attempts affect learning: a review and synthesis. In: Psychology of Learning and Motivation, edited by Ross B. Cambridge, MA: Academic. 2016. 
16.Mcdaniel MA, Roediger HL III, McDermott KB. Generalizing test-enhanced learning from the laboratory to the classroom. Psychon Bull Rev 2007;14: 200-206.
17. Soderstrom NC, Kerr TK, Bjork RA. The critical importance of retrieval-and spacing-for learning. Psychol Sci 2016; 27: 223-230. 